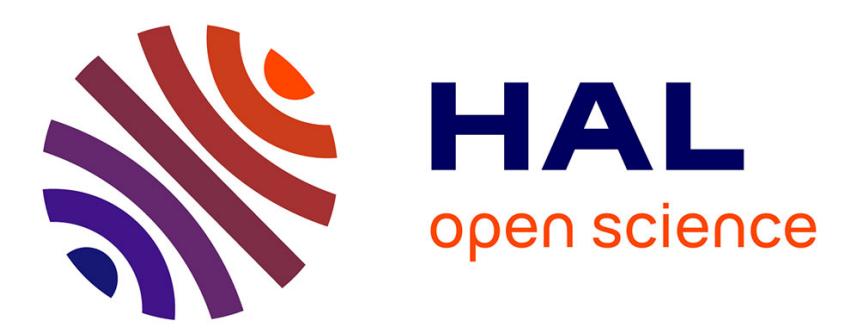

\title{
Trimethoprim susceptibility in E. coli community-acquired urinary tract infections in France
}

C. Duployez, jerome robert, A. Vachée

\section{To cite this version:}

C. Duployez, jerome robert, A. Vachée. Trimethoprim susceptibility in E. coli community-acquired urinary tract infections in France. Médecine et Maladies Infectieuses, 2018, 48 (6), pp.410-413. 10.1016/j.medmal.2018.03.010 . hal-03127583

\section{HAL Id: hal-03127583 \\ https://hal.science/hal-03127583}

Submitted on 24 Feb 2021

HAL is a multi-disciplinary open access archive for the deposit and dissemination of scientific research documents, whether they are published or not. The documents may come from teaching and research institutions in France or abroad, or from public or private research centers.
L'archive ouverte pluridisciplinaire HAL, est destinée au dépôt et à la diffusion de documents scientifiques de niveau recherche, publiés ou non, émanant des établissements d'enseignement et de recherche français ou étrangers, des laboratoires publics ou privés. 
Sensibilité au triméthoprime dans les infections urinaires à $E$. coli communautaires en France

Trimethoprim susceptibility in $E$. coli community-acquired urinary tract infections in France

C Duployez ${ }^{1}$, J Robert ${ }^{2,3,4}$, A Vachée ${ }^{1,2, *}$; on behalf of ONERBA

${ }^{1}$ Laboratoire de microbiologie, CH Roubaix, 59100 Roubaix, France

${ }^{2}$ Conseil Scientifique de l'Observatoire National de l'Épidémiologie de la Résistance Bactérienne aux Antibiotiques, 75006 Paris, France

${ }^{3}$ Sorbonne Universités, UPMC Univ Paris 06, CR7, INSERM, U1135, Centre d'Immunologie et des Maladies Infectieuses, CIMI, Team E13 (Bactériologie), Paris, France

${ }^{4}$ Bactériologie-Hygiène, Hôpitaux Universitaires Pitié Salpêtrière - Charles Foix, APHP, F-75013 Paris, France

*Corresponding author: Anne Vachée

Laboratoire de microbiologie, CH Roubaix, 59100 Roubaix, France

Email: anne.vachee@ch-roubaix.fr

Phone: +33 3.20.99.31.40

Fax: +33 3.20.99.31.39

Mots clés : infections urinaires, Escherichia coli, triméthoprime

Keywords: Escherichia coli, trimethoprim, urinary tract infections

\section{Acknowledgments}

Participating laboratories (biologist): SBL BIO (Hubert Banctel); LPA (Xavier Bertrand); CBM25 (Xavier Bertrand); CHRU Besançon (Xavier Bertrand); Hôpital Joseph Ducing (Aurélie Bouige); CH du Pays d'Aix (Natalie Brieu); AX BIO OCEAN (Geneviève Cous); Laboratoire JF Culard (Jean-François Culard); Hôpital Emile Muller (Jean-Marie Delarbre); Hôpital Antoine Beclère (Florence Doucet-Populaire); Laboratoire ATOUTBIO (Sébastien Fougnot); SELARL MED-LAB (Isabelle Gaillardot); BIOLAB AVENIR (Jean-Louis Galinier); Hôpital Saint-Camille (Hélène Garrec); LABOSUD PROVENCE BIOLOGIE MARTIGUES JONQUIERES (Gisèle Gay); CH Meaux (Karine Grenet); CH Coulommiers (Karine Grenet); CH Marne La Vallée (Karine Grenet); C+BIO (Frédéric Grobost); Laboratoire Schuh Bio67 (Thomas Gueudet); LABOSUD 
PROVENCE BIOLOGIE MARSEILlE (Pierre Hance); $\mathrm{CH}$ d'Armentières (Anne-Cécile Hochart); CHU Le Kremlin Bicetre (Asma Jeblaoui); LBM AMBIO (Sandrine Jobert); CH Dr Schaffner (Sylvie Ledru); Hôpital beaujon (Véronique Leflon); CHU Lille (Caroline Loïez, Frédéric Wallet); CH Dron (Pierre Patoz); CERDIBIO CHARENTES (Gérard Payro); Hôpital de la Pitié-Salpêtrière (Claudio Garcia-Sanchez); DYOMEDEA (Jacques Thierry); CH de Roubaix (Anne Vachée); CH Duchenne (Stéphanie Van Agt); CH de Sambre-Avesnois (Manica Vasseur); BIO-VSM LAB (Philippe Weber)

\section{Contributions of authors}

C. Duployez gathered the results, analyzed the data, and wrote the article.

J. Robert and A. Vachée wrote the study protocol and sent the questionnaires, collected results from the 35 laboratories, performed statistical analysis, and contributed to reviewing and approving the article. 


\section{RÉSUMÉ}

Objectifs. - Le triméthoprime a été récemment introduit dans les recommandations françaises pour le traitement des infections urinaires. Devant l'absence de données épidémiologiques, notre objectif était de déterminer le taux de sensibilité des souches de E. coli responsables d'infections urinaires communautaires chez les femmes jeunes.

Matériels et méthodes. - Enquête nationale prospective sur 350 souches de E. coli isolées d'urines incluses par 35 laboratoires et antibiogrammes réalisés par chacun des laboratoires participants.

Résultats. - Le taux de sensibilité au triméthoprime était de $78 \%$. Les catégorisations cliniques au triméthoprime et au cotrimoxazole étaient équivalentes pour $97,4 \%$ des isolats. Il existait une association entre la résistance au triméthoprime et à d'autres familles d'antibiotiques.

Conclusion. - Nos résultats appuient les nouvelles recommandations proposant le triméthoprime comme traitement de seconde ligne sur la base des résultats de l'antibiogramme. Les taux de sensibilité au triméthoprime et au cotrimoxazole restent très similaires en France. 


\section{ABSTRACT}

Objectives. - Trimethoprim has been recently included in the French guidelines for the treatment of urinary tract infections, but no epidemiological data supports its use. We aimed to determine the trimethoprim susceptibility of $E$. coli isolates responsible for community-acquired urinary tract infections in women of childbearing age.

Materials and methods. - We conducted a national prospective survey. A total of 350 strains of E. coli isolated from urines in 35 laboratories were included. Antibiotic susceptibility testing was performed in each laboratory.

Results. - We reported a susceptibility rate of $78 \%$, and a similar clinical categorization between trimethoprim and cotrimoxazole for $97.4 \%$ of isolates. We pointed out an association between resistance to trimethoprim and other antibiotic classes.

Conclusion. - The results support trimethoprim as a second-line therapy based on antibiotic susceptibility testing. We confirm that trimethoprim and cotrimoxazole susceptibility rates are very close. 


\section{Introduction}

Urinary tract infections (UTIs) are one of the most common causes of medical consultation and antibiotic use in women in community settings. Escherichia coli is responsible for most of these infections and the constant increase in antibiotic resistance among this species is worrisome. Trimethoprim (TMP) is a former antimicrobial agent that is active against Enterobacteriaceae. It acts by competitive inhibition of dihydrofolate reductase (DHFR), and mutations in the $d f r$ genes are the most common mechanisms of TMP resistance [1]. In France, TMP is usually combined with sulfamethoxazole in a single pill but it was recently launched as a single drug for treating cystitis [2]. Indeed, TMP alone has been shown to be as effective as fosfomycin-trometamol, fluoroquinolones, or trimethoprim-sulfamethoxazole (SXT) for treating cystitis [3]. In addition, a recent European study reported equivalent resistant rates for TMP and SXT [4]. Recent French guidelines for UTIs management in women recommend TMP alone as an alternative drug for treating all types of cystitis including cystitis in pregnant women and recurrent cystitis [3]. However, recent data on the susceptibility to TMP alone of E. coli isolated from urines is lacking in France, and guidelines are usually based on SXT susceptibility test results. Thus, we sought to determine the TMP susceptibility of E. coli isolates responsible for communityacquired UTIs in women of childbearing age.

\section{Materials and methods}

We conducted a national prospective survey with 35 laboratories participating to the French National Observatory for Epidemiology of Bacterial Resistance to Antibiotics (French acronym ONERBA). All E. coli isolates from urine samples with a significant bacteriuria $\left(>10^{3} \mathrm{CFU} / \mathrm{mL}\right)$ drawn from ambulatory women aged 15-45 years were included between June 1 and 30, 2016. Patients with an indwelling urinary catheter or recent hospitalization $>48$ hours were excluded. Duplicates were excluded. Species identification and antimicrobial susceptibility testing (AST) were performed in each participating laboratory. TMP susceptibility was determined by the disk diffusion method for 24 laboratories and by automated liquid methods for 11 laboratories. Susceptibility to other antibiotics was determined by the disk diffusion method for 13 laboratories and by automated methods for the 22 other laboratories. AST results were interpreted in accordance with the Antibiogram Committee of the French Society for Microbiology (French acronym CA-SFM) guidelines, which are very similar to European guidelines [5]. The ATCC 25922 E. coli strain was used as a quality control in each laboratory. 


\section{Results}

A total of 350 isolates were included by 16 private practices $(n=159,45.4 \%)$ and 19 hospital laboratories $(n=191$, 54.6\%). AST results are presented in Table I. Only three (1\%) E. coli isolates produced extended-spectrum betalactamase (ESBL). Overall, 273 (78.0\%) isolates were susceptible to TMP including two of the ESBL-producing isolates. None of the isolates were in the intermediate clinical category. A total of 49 of the 77 resistant isolates were tested by the disk diffusion method and had no inhibition zone around the TMP disk. Isolates from hospital laboratories were less frequently susceptible to TMP (74.4\%) than those from private laboratories $(82.4 \%)$, but the difference was not statistically significant $(P=0.09)$. However, isolates from hospital laboratories were less frequently susceptible to SXT $(75.4 \%)$ than those from private laboratories $(85.4 \%, P=0.02)$. There were no other differences in antibiotic susceptibility of isolates according to the type of laboratory. Among the 296 isolates with information on the pregnant status of the patient, TMP susceptibility of isolates from pregnant women was $70.3 \%$, not significantly different than that of non-pregnant women $(78.8 \%, P=0.15)$. The frequency of susceptibility to other antibiotics was not statistically different among pregnant and non-pregnant women. There was a good correlation between TMP and SXT susceptibility: only two (2.9\%) of the 70 SXT-resistant isolates were TMP-susceptible and seven (2.5\%) of the 278 SXT-susceptible isolates were TMP-resistant. As previously described [2,6], TMP resistance was associated with other resistance determinants (Table I). Compared with the 273 TMP-susceptible isolates, the 77 TMP-resistant isolates were significantly less likely to be susceptible to gentamicin (93.5\% versus $99.3 \%$ ), ciprofloxacin $(88.3 \%$ versus $97.0 \%$ ), and of course SXT (9.3\% versus $99.3 \%)$. Overall, TMP-resistant isolates were less likely to be susceptible to other antibiotics, but differences were not statistically significant.

\section{Discussion}

We report a resistance rate to TMP of $22.0 \%$ (29.7\% for pregnant women) among 350 isolates of E. coli isolated from urinary samples of women of childbearing age. This rate is rather high and prevents any use of TMP as an empirical drug for UTI in this population before AST [3]. However, experiences of other European countries suggest the benefit of using TMP alone for treating UTI, and TMP may therefore remain of interest as a secondline therapy. 
Our study brings two information of interest for clinicians. First, we confirm that TMP and SXT susceptibility rates are very close. Hence, SXT susceptibility result could be used as a surrogate for TMP susceptibility, and TMP could be an alternative to SXT to avoid the adverse effects of sulfamethoxazole. However, TMP advantages over SXT for treating UTI in pregnant women remain debatable [7]. Second, resistance to TMP is often associated with resistance to other antibiotics. Hence, although TMP is a theoretical alternative for treating UTI infections due to resistant bacteria because of a lack of cross-resistance, the frequency of associated resistance may decrease its benefit. In addition, a review of the literature points out an increase in TMP resistance after its wide use as a single drug [8] and in other antibiotics [2]. Moreover, the decreased use of TMP does not reduce TMP resistance rate caused by the low fitness cost of this resistance, combined with co-selection due to high levels of other resistance determinants [2,6].

\section{Conclusion}

The use of TMP as a first-line agent in women presenting with UTI is not warranted by its susceptibility rate. This result supports the recent French guidelines, recommending the use of TMP as a second-line agent based on AST. The results support TMP use instead of SXT for such infections. However, the association with other resistance determinant may preclude its use for the treatment of multidrug-resistant bacterial infections.

CONFLICTS OF INTEREST: none 


\section{REFERENCES}

1. Brolund A, Sundqvist M, Kahlmeter G, Grape M (2010) Molecular characterisation of trimethoprim resistance in Escherichia coli and Klebsiella pneumoniae during a two year intervention on trimethoprim use. PLoS One. 16;5(2):e9233. doi: 10.1371/journal.pone.0009233.

2. Société de Pathologie Infectieuse de Langue Française (SPILF). Diagnostic et antibiothérapie des infections urinaires bactériennes communautaires de l'adulte. Recommandations - Argumentaire 2015. http://www.infectiologie.com/UserFiles/File/spilf/recos/infections-urinaires-spilf-argumentaire.pdf. Accessed 10 April, 2017

3. Haute Autorité de Santé. Commission de la transparence Triméthoprime. 22 juin 2016. http://www.hassante.fr/portail/upload/docs/evamed/CT-13148_DELPRIM_PIC_INS_Avis1_CT13148.pdf. Accessed 10 April, 2017

4. Kahlmeter G, Poulsen HO (2012). Antimicrobial susceptibility of Escherichia coli from community-acquired urinary tract infections in Europe: the ECO-SENS study revisited. International Journal of Antimicrobial Agents. $1 ; 39(1): 45-51$.

5. Comité de l'Antibiogramme de la Société Française de Microbiologie. CASFMV2_030915. http://www.sfmmicrobiologie.org/UserFiles/files/casfm/CASFMV2_030915.pdf. Accessed 10 March 102017

6. Sundqvist M1, Geli P, Andersson DI, Sjölund-Karlsson M, Runehagen A, Cars H, Abelson-Storby K, Cars O, Kahlmeter G (2010). Little evidence for reversibility of trimethoprim resistance after a drastic reduction in trimethoprim use. J Antimicrob Chemother. 65(2):350-60. doi: 10.1093/jac/dkp387.

7. Hernándes-Díaz S, Werler MM, Walker AM, Mitchell AA (2000). Folic acid antagonists during pregnancy and the risk of birth defects. N Engl J Med. 30;343(22):1608-14.

8. Towner KJ, Smith MA, Cowlishaw WA (1983). Isolation of trimethoprim-resistant, sulfonamide-susceptible Enterobacteriaceae from urinary tract infections. Antimicrob Agents Chemother.23(4):617-8. 
Table 1. Antibiotic susceptibility (\%) among the 350 isolates from ambulatory female patients

Tableau 1. Sensibilité aux antibiotiques de 350 souches isolées chez des patientes ambulatoires

\begin{tabular}{|c|c|c|c|c|c|}
\hline Antibiotics & All & Pregnant & & Trimethop & \\
\hline & $\begin{array}{l}\text { Isolates } \\
(n=350)\end{array}$ & $\begin{array}{l}\text { Yes } \\
(n=74)\end{array}$ & $\begin{array}{l}\text { No } \\
(n=222)\end{array}$ & $\begin{array}{l}\text { Susceptible } \\
(n=273)\end{array}$ & $\begin{array}{l}\text { Resistant } \\
(\mathrm{n}=77)\end{array}$ \\
\hline Trimethoprim & 78.0 & 70.3 & 78.8 & - & - \\
\hline Co-trimoxazole & $\begin{array}{l}79.9 \\
(n=348)\end{array}$ & 71.6 & $\begin{array}{l}80.9 \\
(n=220)\end{array}$ & 99.3 & $9.3^{*}$ \\
\hline Fosfomycin & $\begin{array}{l}99.7 \\
(n=321)\end{array}$ & $100.0(n=63)$ & $\begin{array}{l}99.5 \\
(n=203)\end{array}$ & 99.6 & 100.0 \\
\hline Nitrofurantoin & 99.4 & 100.0 & 99.1 & 99.6 & 98.7 \\
\hline Nalidixic acid & $\begin{array}{l}88.8 \\
(n=349)\end{array}$ & 93.2 & $\begin{array}{l}87.8 \\
(n=221)\end{array}$ & 93.8 & $71.1^{*}$ \\
\hline Ciprofloxacin & 95.1 & 97.3 & 94.1 & 97.0 & $88.3 *$ \\
\hline Co-amoxiclav $^{\circ}$ & 93.1 & 96.0 & 92.8 & 94.5 & 88.3 \\
\hline Mecillinam & $\begin{array}{l}95.5 \\
(n=311)\end{array}$ & $96.3(\mathrm{n}=54)$ & $\begin{array}{l}94.6 \\
(n=203)\end{array}$ & 96.7 & 90.9 \\
\hline Cefoxitin & 99.1 & 98.7 & 99.1 & 99.6 & 97.4 \\
\hline Ceftriaxone/cefotaxime & 99.1 & 98.7 & 99.1 & 99.3 & 98.7 \\
\hline Ceftazidime & 99.4 & 98.7 & 99.6 & 99.6 & 98.7 \\
\hline Piperacillin-tazobactam & $\begin{array}{l}97.9 \\
(n=341)\end{array}$ & $98.6(n=71)$ & $\begin{array}{l}97.7 \\
(n=216)\end{array}$ & 98.5 & 96.1 \\
\hline Carbapenem & $\begin{array}{l}100.0 \\
(n=341)\end{array}$ & $100.0(n=71)$ & $\begin{array}{l}100 \\
(n=216)\end{array}$ & 100 & 100 \\
\hline Amikacin & $\begin{array}{l}98.3 \\
(n=348)\end{array}$ & $98.6(n=73)$ & $\begin{array}{l}97.7 \\
(n=221)\end{array}$ & 97.8 & 100.0 \\
\hline Gentamicin & 98.0 & 100.0 & 100.0 & 99.3 & $93.5^{*}$ \\
\hline
\end{tabular}

${ }^{\circ}$ Urinary breakpoints [5]

$* P$ value $<0.05$ 